\title{
The Tsunami: a wake-up call for north and south
}

\author{
by Dr C Chatterjee
}

The author examines the socio-economic effects of the disaster, and considers the functions of aid in this type of situation.

\section{INTRODUCTION}

$\mathrm{T}$ The Tsunami disaster touched everybody's heart in the world. It was a natural disaster of unprecedented scale which aroused emotion and a sense of responsibility in every sensible human being. Whether the governments for the countries concerned acted responsibly in taking precautionary measures is an issue which may provoke controversy, and the game of political "ping pong" on this issue will go on for some time in the future.

The purpose of this article is not to deal with the emotional aspects of the disaster, but to examine the socioeconomic effect of the catastrophe, the plight of the survivors, the environmental effect of the disaster, and the issue of the reconstruction of these economies. It is emphasised that in developing the ideas in this article, no academic controversies relating to economic development have been accorded any priority; the article deals with what the author believes to be the reality of the current situation.

\section{WAS THE RISK FORESEEABLE?}

Risks may be categorised into four categories: (a) foreseen; (b) foreseeable; (c) unforeseen; and (d) unforeseeable. It is reported, albeit unofficially, that certain local experts warned their governments of the disaster beforehand; and from this point of view the risks were foreseen. However, the official view may be that as such a disaster had never happened in these areas, why should the government concerned spend time on anticipatory work?

It is also understood from unofficial sources that the experts in certain countries who managed to forecast the disaster had no idea who to inform about it. The fact remains that even if the risk was anticipated, the scale of the disaster was so extensive that no insurance policy, if enforced, would be able to provide the cover. In addition, no government, rich or poor, would have been able to take any appropriate measures to counteract the disaster other than by raising alarms to tourists against visiting those areas, and providing shelters to the population in the now affected areas in safe areas. But, given the extent of the disaster, would they have been able to return to those areas soon afterwards? The answer is certainly in the negative. The effect of the disaster may not be counteracted over a short period of time. Furthermore, what precautionary measures could be taken in such circumstances, bearing in mind that many people, particularly the fishing community, live near the coast lines in India, Indonesia, the Maldives, Sri Lanka or Thailand? In rich countries too, fishing communities live by the coast, but in well-built villages and resorts with strong foundations. Furthermore, one must remember that the countries affected by the Tsunami, however poor they might be, have always been regarded as tourist attractions; tourism has always been one of their principal sources of income, and tourist spots have never been built to the standards which may be found in rich countries.

Thus, blame should not be placed on any particular institution. The extent of the disaster was simply unprecedented and unacceptable. The consequences are immeasurable; the economic effect is far-reaching, and the scale of human tragedy is simply unimaginable.

\section{THE FORESEEABLE CONSEQUENCES OF THE DISASTER}

The following are the foreseeable consequences of the disaster, and the actions to be taken in consequence:

- homelessness (the term "refugees" which has been used by certain reporters in the media is incorrect, because none of the affected individuals have, so far, fled his/her affected country to find refuge in another country);

- health hazards (outbreak of diseases);

- environmental problems;

- traumatic effect on the affected people;

- economic losses for the families and the countries concerned arising from the loss of industries, and other sources of income;

- the need for rehabilitation of the survivors from the affected areas; 
- an urgent need to create employment for the displaced persons and firms;

- re-establishment of industries, particularly tourism and related industries;

- reconstruction of resorts etc;

- rebuilding confidence in the minds of future tourists;

- returning the affected local people to their original areas;

- urbanisation of rural areas without distorting the rural attractions; and

- the development of infrastructure in the affected areas.

Money and time are required to achieve these; meanwhile, the affected countries will be very heavily dependent on foreign loans; in other words, their debt burdens will be very heavy culminating in a cycle of poverty.

\section{THE ISSUE OF AID}

The magnitude of human generosity in giving aid to the affected people is praiseworthy. Perhaps never before in living history has so much help, financial or otherwise, been given and pledged to any disaster-stricken area and people. But what are the functions of aid?

Aid in such circumstances provides relief on a temporary basis which includes basic items for sustenance, looking after the injured / wounded, shelter, and medical and health matters. Aid cannot re-create a nation, and in this case, several nations have been very adversely affected. So far, US\$ 4 billion has been pledged, which is not enough for infrastructural development or the rehabilitation of the affected people.

Aid which is emotion-based certainly serves a purpose, but of a basic humanitarian nature. Aid is essential for initial relief, and it can reduce the death toll, but aid-giving is neither preventative nor curative - its aim is to provide relief. However, aid can have a dependency effect, unless the beneficiaries are rehabilitated rather speedily. Furthermore, in developing countries in particular, during camp-life (short-term shelter-life) children usually do not have any access to education. All the symptoms of poverty become manifest. In developing countries, people remain in such an unfortunate situation for a long time, and camp life eventually becomes their life style.

Therefore, aid which is essential at the initial stage to provide relief must be accompanied by rehabilitation of the dispossessed, and employment-creating projects to rebuild their capacity to work. As part of this process, education for both children and adults must also be promoted at both primary and secondary levels. One of the negative aspects of aid-giving is that it can make a government less proactive; when government services are proved to be under-performing, then the justification for giving financial aid for development purposes should be questioned. According to the World Bank, substantial research shows that aid is productive in countries with good policies and institutions (see World Development Report 2004, (Making Services Work for Poor People), Washington DC, World Bank at 11; World Bank Reports, 1998a and 2002a). Furthermore, without a programme of efficient public spending, foreign aid is unlikely to provide any substantial benefits, and the productivity of public spending varies significantly from country to country. The World Development Report 2004 also points out that whereas Ethiopia and Malawi spend roughly the same amount per person on primary education but produced very different outcomes, Peru and Thailand spend significantly different amounts but produced similar outcomes. In financial aidgiving for socio-economic development, three-way relationships should be maintained between client and provider; citizen and policy-maker; and policy-maker and provider. Donors should not by-pass any of these relationships.

Instead of placing extraordinary emphasis on financial aid - important though that is - donors should help generate knowledge. A sector-wide approach should be taken on health, education etc; donors should align their plans with the recipient's development strategy, budget and other resources, and they should not donate with any ulterior motive. It is essential that donors perform in line with a government's policy rather than by-passing it (the adverse effect of by-passing the natural engineering departments in Bangladesh became evident in connection with the Bangladesh Arsenic Mitigation Water Supply Project: see further World Development Report 2004 (The World Bank) above at 206). Aid, without any technical assistance allocated to it, can be habit-forming. Performance-related aid is better than aid without accountability, and nothing can be better than accountability to itself with justification. Technical assistance is a vitally important factor of endogenous growth process; it should be knowledge and skills-based, because knowledge and skills stand for technology. Knowledge-building minimises the need for acquiring technology. With earned knowledge and skills, indigenous technology should be suitable for indigenous purposes.

In its Report entitled Transnational Corporations in World Development, the UN stated that:

"There is growing realization, although with varying degrees of emphasis and initiative, that an indigenous technological capability is a necessary condition for the evaluation of technology to be obtained from abroad, for the effective utlization of the transferred technology, for its adaptation to local conditions, for getting better terms for the transfer in negotiations with foreign enterprises and for the generation of 'appropriate' indigenous technologies. In other words, indigenous technologies capability is not an alternative to transfer but a necessary condition for it" (UN Centre for 
Transnational Corporations, Transnational Corporations in World Development, New York (1985) at 50).

"Aid" should stand for technical assistance to be reinforced by manageable financial assistance, where necessary. The recipient country's ability to service the loan (manageable) is an important factor for the determination of the quantum of financial assistance. This is where foreign technical assistance becomes necessary, along with a universal understanding for taking a comprehensive view of the problems of development.

It is very encouraging to see the speed at which very large amounts of aid are being given by various Western countries. In the circumstances aid is essential to overcome the initial rescue operations and short-term rehabilitation or medical help. Incidentally, when the tragedy took place in Bhopal, India and affected over 200,000 people, foreign aid did not materialise in the same way and in a similar quantity, perhaps because it was almost a US-India affair. Not many foreign lives were lost in the incident. With the Tsunami, a very large number of foreign tourists lost their lives. Aid provided the fuel to the rescue work and assistance to the countries concerned in their plight.

Rapidly delivered aid is extremely useful, but may not necessarily beneficial for reconstructing the economies of these countries. In many cases, development of infrastructure would be necessary. Do these countries have sufficient capital and/or expertise to re-develop it? Aid may not lead to economic self-sufficiency, but if the infrastructure of a country is properly developed, development and self-sufficiency become evident. Take, for example, the case of India. During the early period of her independence from the British, India was given loans and aid from various sources, and yet essential infrastructure was not developed - not because the country did not realise the importance of it, but because economic plans suggested by various experts did not, in reality, encourage growth and self-sufficiency.

It would be inappropriate to go into the details of this issue in the context of this article, but one may like to reflect on how Meir and Rauch summarised this problem: at various times economists stressed increasing returns as an endogenous explanation for economic growth. Adam Smith emphasised that growth in productivity was due to the division of labour. The role of "nature" in production according to Alfred Marshall might be subject to diminishing returns, whereas the role of "men" would be subject to increasing returns. J M Clark observed the "knowledge" was the only instrument of production which would not be subject to diminishing returns (J Maurice Clark, Studies in the Economics of Overhead Costs (1923) at 120). Arrow emphasised the policy of "learning by doing" (K Arrow, "The economic implications of learning by doing”, Review of Economic Studies (June 1962) 155-73.

The new endogenous growth theory examines production functions that show increasing returns because of specialisation and investment in "knowledge" capital. Investment in knowledge deserves priority. Inherent in the endogenous growth theory is the issue of technological progress and development of human capital. The longterm return of this model of endogenous growth should by its spill over effect aid the other related sectors; thus this model has a multiplier effect. The endogenous growth model should conform to the needs of diversity in growth, which is particularly required in developing countries (see also J K Sengupta, "Growth in NICs in Asia: some tests of new growth theory", Journal of Development Studies (January 1993) 342-57).

On the other hand, Robert Salow's neoclassical growth model showed diminishing returns to capital and labour separately and left technological progress as a residuary matter. However, it might be difficult to deny the rationale on which the endogenous growth theory is based.

Aid alone will not do; technical assistance and development through indigenous technology would be essential. This point has been further developed in section 6 of this article.

\section{THE SCENARIO}

Each of the countries affected by the Tsunami (India, Indonesia, the Maldives, Sri Lanka and Thailand, plus certain parts of Africa) has large coastlines. The coastal economy contributes significantly to the national economy in these counties, particularly in Indonesia and Sri Lanka. In the Maldives, fishery and tourism are the primary sources of income, while Thailand's natural beauty has always attracted tourists to her seaside resorts.

Interestingly enough, coastal areas in the developing parts of the world are mostly inhabited by poor people who rely on an unsophisticated fishing industry or other labourintensive sources of income, be they artefacts, clay models or the like. They usually live in modest houses, in fact in many cases huts of very weak foundations. Development of the coastal communities often does not receive governmental priority.

Foreign tourists find that life style attractive, close to nature and free of urban pollution. Most of the hotels or guest houses are cheap and thus lack sophistication. They cater for budget holidaymakers. Perhaps governments do not see a need for changing the environment for fear of jeopardising the flow of tourists. Iit is noteworthy that no properly built houses or bridges were collapsed by the waves.

By contrast, coastal people in the Western World, irrespective of their profession, do not live in a poor condition. They are also the beneficiaries of state benefits, where eligible. In most developing countries health and safety regulations are not as rigidly enforced as they are in rich countries. Perhaps an appropriate enforcement of these regulations would have required them to build safe 
hotels and guesthouses - but that would cost them money. Hence the need for investors to build structurally dependable hotels and guestrooms.

It is interesting that both the host countries and the tourists seem to have taken it for granted that nothing untoward would take place in the traditional tourist spots in South East Asia. Nobody thought of the risks, and no investment company, whether local or foreign, found it necessary to strengthen the infrastructure of the tourist industry. Risks (on a much lesser scale to what took place on December 26, 2004) in the form of cyclones, storms flood and the like were foreseeable, but neglected. Tourists found these South East Asian countries not only alternative but also cheap.

When one reflects on such incidents in the developing parts of the world, every single coastal state is subject to such disasters, particularly because of the quality of the houses in which the coastal people live, and the resorts in which foreign tourists stay. It is not much a matter of funds; it is a matter of policy, which should be implemented with technical assistance, where necessary. The Tsunami disaster should serve as a grim lesson to developing countries that tourist spots and tourism industry must have reliable foundations.

\section{PRIMARY DIFFERENCES IN PERCEPTIONS BETWEEN THE NORTH AND THE SOUTH}

One could start by thinking how the Tsunami disaster may be related to the differences between the North and South. The South, in general, has remained poor, but is nevertheless full of natural resources and natural beauty; the latter has the capacity to attract visitors from the North at a cheap cost. Visitors visit the historical places; they look at the way poor people live, return to their homelands, and probably discuss the differences between the North and the South. The debate ends there. The fragile conditions of the ordinary guest-houses and the state of the roads have never been a matter of concern for visitors. It predominantly fell on the government concerned to raise funds from various sources to repair or re-construct whatever may be necessary, thus increasing the debt burden. This phenomenon is not present in the North to the extent that it affects the South.

Apart from a few countries such as Japan or Italy, or perhaps the State of Florida in the US, the North does not usually experience the kind of natural disasters that the South experiences, whether in Africa or Asia. It should be pointed out however that the vast majority of the poor countries are tropical countries; they live with diseases. Nature is much more cruel to developing countries than it is to developed countries, having a direct effect on their economic development process and keeping them disadvantaged. However emotional it might sound, these are some of the mundane facts one must be prepared to accept. However, economic prosperity may be achieved if, for example, a platform for North-South co-operation is formed - such as that which originated in the 1970's under the Chairmanship of the West German Chancellor Willy Brandt, but was eventually allowed to die its natural death.

There are a variety of reasons why developing countries are poor - in many cases undemocratic governments, lack of appropriate policies, adverse climatic conditions, high population growth, corruption, unreliable judicial systems, the lack of education, general poverty etc. But remedial measures may be made available through both internal and external action, the latter in this context being a united international community. Developing countries should not be generally apprehensive of encroachment upon their sovereignty; instead they should do everything possible to build confidence in the minds of private foreign investors. There is no reason why, through international efforts, work on the national infrastructure cannot be carried out in the developing world, and nor is there any reason why, through the same efforts, suitable industries may not also be set up.

The lending of money alone, without technical assistance attached to it, simply overburdens the borrower. The borrower's objectives may not be achieved, and thus supervision of projects by lenders is essential in order to ensure that the projects carried out with borrowed money are successfully completed and benefit those who they were created to help. Borrowing must be performance-related, and conditional upon accountability.

A more fundamental understanding between North and South as to mutual co-operation is required. If the South is not developed, the North will eventually suffer because their countries will have no market for their products in what is the larger part of the world. Prices of products in the North are beyond the reach of the South. The markets in the North are near saturated; thus, there is an urgent need for creating markets in the South, which may primarily be achieved by what is known as "capacity building". Unless the economies of developing countries are developed, the prospects of exporting products from the rich to the poor will remain distant. This is what was described by the Brandt Commission as one aspect of the "mutual interest". The Commission further pointed out that only if the North provides better access to its own markets can it expect to export more. The fact of the matter is that 90 per cent of the world's manufacturing industry is in the North, and the North is also the home of transnational corporations. The North dominates the international economic system, including its rules, regulations and the international institutions of trade. Distribution of knowledge and skills to the developing world would be beneficial, rather than their being jealously guarded by developed countries. The Brandt Commission rightly pointed out too that a mere recognition of "mutual interest" is not enough; human solidarity and a commitment to "international social justice" are also needed; there must be an end to deprivation and suffering. 
The perception that monopolisation of power economic, military or otherwise - is good for the North is somewhat ill-founded, because it not only causes conflicts between the North and the South, but also widens the gap between these two parts of the world. Take, for example, the issue of the world trade. Leaving aside the platform of the WTO/GATT, one should reflect on the policies recommended by the Doha Declaration; they still remain unimplemented (the text of the Doha Declaration 2001 has been reproduced in 41 International Legal Materials (2002) 746). Take also the example of the Kyoto Protocol (Doc FCCC/CP/1997/L.7/Add. 1 of 10 December 1997).

Can a premature implementation of this Protocol protect the interests of developing countries? What was needed was to prepare developing countries before creating the Protocol. The Kyoto Protocol directly prevents developing countries from gaining market access for many products to developed markets.

Apprehension persists that that cheap products from developing countries would flood the markets in the North, with an adverse effect on employment. But this is another unfounded perception because cheap and quality consumer goods manufactured in the South will enable the North to purchase products at a lower price, and the North can devote itself to its own industries, and scientific innovations and inventions. On the other hand, an opportunity to manufacture products will allow the South to increase the volume of their export trade with the consequential effect of achieving higher skills and knowledge and accumulation of foreign exchange reserves. The North's industrial and scientific might will automatically protect and expand its economic prosperity.

The instability of regimes in the South can generally be attributed to economic backwardness leading to poverty. If the North had taken the initiative and made a concerted effort to deal effectively with the economic backwardness of the South by using the South's indigenous resources, then the incidence of economic conflicts and even international terrorism would have been lessened. The gap of economic prosperity between the rich and the poor precipitates conflicts at both domestic and international levels.

The social effect of this unbridgeable gap has already become evident in the form of economic migration from the poor countries to the rich countries in the North. This sudden influx of economic migration could have been avoided if only the economic conditions in the South had improved through external help. The Brant Commission Report stated that "protectionism hurts", and it still does. The WTO Subsidy Agreement allowing rich countries to provide subsidies on various grounds to inefficient firms by the respective governments is a direct assault on the South's aspirations to gain access to outside markets. From a realistic standpoint, only rich countries can afford to pay subsidies for a long time. It must also be realised that during the period protectionism is fostered by rich countries even more skills are learned by their workers, leading to more efficient production and a further widening of the gap between North and the South.

In the absence of open market access for their manufactured or agricultural products, poor countries are often required to sell their natural resources, which they should not do other than for their own purposes. The question arises whether transnational corporations as the principal agents of exploration and exploitation of natural resources in developing countries should not plough back some of their profits into the economies of developing countries according to their economic development programmes.

The South is not fault-free either. Coercive regimes in many countries have already proved to be an important contributory factor to poverty. Confidence in their own efficiency and skills is often lacking. The lack of recognition of fundamental rights, including the right to education or the right to basic freedoms - freedom of speech, or freedom as to economic rights, or the maintenance of equality within societies - are some of the current features of most developing countries. Poverty leads to corruption; corruption saps the foundation of progress. Herein lies the importance of international co-operation to liberate the poor from corruption and poverty. The countries in the South should also make their best efforts to attain selfsufficiency in their agricultural sectors, and to adopt antipoverty strategy and economic co-operation policies among themselves.

The tourism industry had traditionally been one of the core industries in Asia and Africa, but it has been left to the capacity and planning of the countries concerned, without realising that in the event of any disaster taking place the foreign tourists would suffer. It is an issue which should have been a matter of concern for both North and South. However, the flow of investment from the North to the South is not remarkably high, perhaps for any or all of the following reasons: (a) perception of risks in developing countries; (b) the lack of expertise; (c) legislative uncertainty; (d) judicial risks. But these risks are not necessarily present in all developing countries; furthermore, private foreign investors do have the privilege of making investments in developing countries under the protection of MIGA's insurance policies, and national investment protection schemes, such as the Export Credit Guarantee Department (ECGD) in the UK, or Overseas Private Investment Corporation (OPIC) in the United States. Investment flow from the North to particular developing countries increases when the latter have achieved what is known as "economic take-off". China and India come under this category.

A "catch 22" situation exists: private foreign investors (transnational corporations) may not find it profitable to invest in developing countries until the latter has developed 
a platform for investment, but on the other hand such platforms often cannot be developed without the help of private foreign investors. Thus, developing countries are required to achieve what is known as "capacity building" with the aid of international assistance. They should have confidence in themselves; they have human resources and natural resources, and need to increase knowledge and skills to develop their own technology. This will also help them keep their foreign debt burden under control by not importing inappropriate technology from the North.

\section{THE ROLE OF INTERNATIONAL ORGANISATIONS IN ECONOMIC DEVELOPMENT}

So long as profit-maximisation remains the primary goal of private foreign investors one cannot possibly expect them to be involved in infrastructural development programmes, general economic development progress, or any other programme which may not be earning high profits. Infrastructural development programmes thus fall on governments to carry out. Finance is usually provided by international economic institutions, namely the World Bank, including International Finance Corporation, the International Development Association, and in certain cases, the International Monetary Fund. Other institutions, such as the International Development Department in the UK or other governmental agencies, often provide funds to developing countries on such projects. It is primarily a government's responsibility to develop and maintain infrastructure, communication, health and welfare, including transport systems; indeed governmental involvement in such projects is preferable in that it should be more fully aware of what may be needed in the context of its own country than outside agencies.

Finance from international institutions is often allowed along with technical assistance, which is extremely useful for developing countries. Furthermore, assistance from these organisations is not profit-based. With financial and technical assistance from abroad, most developing countries should be able to develop their indigenous technology for the manufacture of consumer products. This is not to suggest that transnational corporations should be prevented from engaging in these activities, but it must be remembered that they are profit-making organisations. These corporations may be invited when a developing country decides to set up high technologybased sophisticated industries such as communications, aircraft etc. In the mining and petroleum sectors, for example, transnational corporations do already operate in many developing countries. These activities and development projects are different in nature, in that the latter is concerned with activities of a fundamental nature, irrespective of whether the end result is profit-making or not. The outcome must contribute to the welfare of the state, unless a particular project is supposed to be profitmaking.
If often falls on international organisations to come to the rescue of the plight of developing countries. In order to encourage private foreign investors to increase their investment in the developing world, the Multilateral Investment Guarantee Agency (MIGA) was set up in 1985, under the auspices of the World Bank. Under this scheme, most of the usual risks associated with private foreign investments in the developing world, except lawful expropriation risk, are covered (See further, I Shihata, MIGA and foreign investment: origins, operations, policies and basic documents, Martinus Nyhoft (1988); see also S K Chatterjee, "The Convention Establishing the Multilateral Investment Guarantee Agency," 36 International and Comparative Law Quarterly (1987) 76-91).

This latter risk is not covered because under the principle of state responsibility, an expropriating state has the obligation to pay appropriate compensation when expropriation takes place in the national interest.

Article 2 of the Convention identified MIGA's objectives and purposes, which are to encourage the flow of investments for productive purposes among member countries and, in particular, to developing countries. To serve its objectives, MIGA shall:

(a) issue guarantees, including re-insurance and reinsurance, against non-commercial risks in respect of investments in a member country which flow from other member countries;

(b) carry out appropriate complementary activities to promote the flow of investments to and among developing countries; and

(c) exercise such other incidental powers as shall be necessary or desirable in the furtherance of its objectives.

Under the Convention, the following types of risk may be covered:

(a) Risks relating to currency transfer in a freely usable currency or another currency acceptable to the holder of the guarantee.

(b) Expropriation and similar measures (including legislative or administrative action) which will have the effect of depriving the holder of a guarantee of his ownership or control or a substantial benefit from his investment, but not nondiscriminatory measures of general application which governments normally take for the purpose of regulating economic activity in their territories (Art 11(a)(ii)).

(c) Breach of contract by the host government concerned and, when the investor will not have recourse to a judicial or arbitral body to determine the claim due to repudiation or breach, when a decision by such bodies will not rendered within a reasonable period of time or when their decision may not be enforce.

(d) Loss or damage to an investment due to war and civil disturbance occurred in the host country. 
Upon the joint application of the investor and the host country, the Board of Directors of MIGA may, by special majority, extend the guarantee to cover specific noncommercial risks also. Losses resulting from the following shall not be covered:

(a) any host government action or omission to which the holder of the guarantee has agreed or for which he has been responsible; and

(b) any host government act or omission or any other event occurring before the conclusion of the contract or guarantee (Art 11(b)(ii)).

During the fiscal years 2001-2004 projects were insured by MIGA in the following countries:

\begin{tabular}{|c|c|}
\hline 2001 & 2002 \\
\hline Albania & Benin \\
\hline Angola & Bosnia and Herzegovina \\
\hline Argentina & Brazil \\
\hline Bosnia and Herzegovina & Bulgaria \\
\hline Brazil & Costa Rica \\
\hline Costa Rica & Croatia \\
\hline Dominican Republic & Dominican Republic \\
\hline Ecuador & Jamaica \\
\hline Guinea & Kazakhstan \\
\hline Guatemala & Kenya \\
\hline Jordan & Kyrgyz Republic \\
\hline Kazakhstan & Madagascar \\
\hline Moldavia & Mauritania \\
\hline Mozambique & Mozambique \\
\hline Nicaragua & Nepal \\
\hline Pakistan & Nicaragua \\
\hline Panama & Pakistan \\
\hline Peru & Peru \\
\hline Philippines & Romania \\
\hline Romania & Russian Federation \\
\hline Russian Federation & Senegal \\
\hline Slovak Republic & Turkey \\
\hline Tanzania & Ukraine \\
\hline \multicolumn{2}{|l|}{ Togo } \\
\hline Vietnam & \\
\hline Zambia & \\
\hline
\end{tabular}

During the fiscal year 2004, MIGA insured a variety of projects in (a) Asia and the Pacific; (b) Europe and Central Asia; (c) Latin America and the Caribbean; (d) Middle East and North Africa; and (e) Sub-Saharan Africa. MIGA has also been initiating a number of technical assistance activities.

According to the Annual Report for 2004, the following number of guarantees were issued by MIGA between 2000-04:

20002001200220032004

Number of guarantees

$\begin{array}{llllll}\text { issued } & 53 & 66 & 58 & 59 & 55 \\ \begin{array}{l}\text { Number of projects } \\ \text { supported }\end{array} & 37 & 46 & 33 & 37 & 35\end{array}$

Guarantees are issued by MIGA only on those projects which have been chosen by host countries. Perhaps the hotel and tourism industry should receive as much priority as any other basic industry.

The type of project on which insurance policies have been allowed are varied: equity investment in banks; widening of highways; telecommunications; health; consumer loans and short-term business loans; electricity; agriculture; production of synthetic yarn; enlargement of mortgage programmes; logistics services to local and international import-export companies; financing for the supply of high technology diagnostic imaging and variation therapy equipment to hospitals and like institutions; deepsea oil and gas production facilities; manufacturing facilities for telephone, electronic and optic cables; hotel and tourism; construction of onshore bulk-liquid terminal, for the receipt, storage and distribution of liquefied petroleum, gas and diesel fuel, water industry; hydroelectric plant; construction and operation of airports; privatisation of certain economic sector(s); construction of office building(s); selling of flour mills; privatisation, rehabilitation and management of existing sugar industry; transportation facility; export promotion; expansion of car dealership; development of computer software industry; development of efficient telecommunications infrastructure; promotion of economic recovery in the countries most affected by the 1998 Asian financial crisis; legal and regulatory reforms; training and advisory services; hypermarket/shopping mall; construction and operation of brewery; construction and operation of air cargo complex and air catering centre; improvement of banking system; acquisition of lock manufacturing facility; establishment of new investment promotion agency; build, operate and transport (BOT) scheme for the operation of urban rapid rail transportation system; technical assistance particularly to promote FDI; training in the use of on-line business information resources to identify and resource potential investors; methods of developing and managing client relationship management systems, general capacity-building in mining and port development.

This spread of projects looks quite impressive, but given the nature of underdevelopment in most of the developing countries, much more infrastructural work needs to be done. In this context, the participation of the commercial world is needed, not necessarily in the form of transfer of technology, but mostly in the form of transfer of knowledge and skills. Developing countries need advice as to how to develop their own indigenous technology rather than the introduction of high technology from the beginning of their economic development process. In this regard the UN recommendation on "acquisition of foreign technology" is instructive. It emphasises the importance of creating indigenous technology as well as acquiring, when necessary, according to the country's needs. Instead of following the traditional practice of transferring 
technology, transnational corporations should be engaged in transferring skills and knowledge. In its Report entitled "Knowledge for Development (World Development Report, 1998/99) the World Bank stated, inter alia, in this context (at p2) that:

"But developing countries need not reinvent the wheel - or the computer, or the treatment for malaria. Rather than recreate existing knowledge, poorer countries have the option of acquiring and adopting much knowledge already available in the richer countries. With communication costs plummeting, transferring knowledge is cheaper than ever."

It further noted (at p8) that:

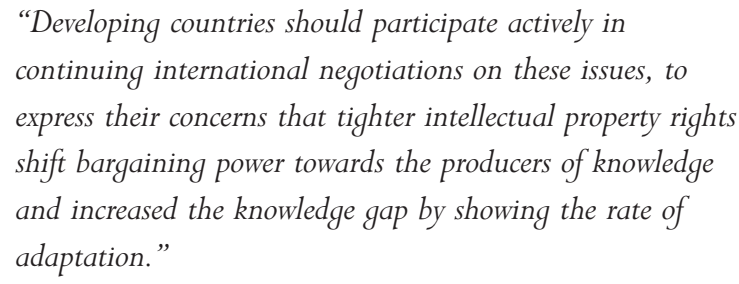

The Report also noted that:

$$
\begin{aligned}
& \text { "Developing countries can take advantage of the large global } \\
& \text { stock of knowledge only if they develop the technological } \\
& \text { competence to search for appropriate technologies and to } \\
& \text { select, absorb and adapt imported technology ... Even in } \\
& \text { manufacturing, knowledge produced in other countries often } \\
& \text { has to be adapted to local conditions, such as weather, } \\
& \text { consumer tastes, and the availability of complementary } \\
& \text { imports. Similarly, prospects in education, health care and } \\
& \text { agricultural extension all require local knowledge that cannot } \\
& \text { be obtained from abroad." }
\end{aligned}
$$

The BOT scheme, in general, should prove to be useful. Industries developed under this scheme benefit both parties. The locals learn skills, the home country's markets are provided with quality products at cheaper and competitive prices. Host countries' employment and wealth grow. North-South differences are predominantly attitudinal and perception-based, often without any rational basis. The needs of the South are often misunderstood by the North in that the latter either worked to transform the former as developed countries, without paying much attention to their infrastructural needs, or that the North had a moral duty as opposed to the economic resources to come to the aid of the South. The fact of the matter is that without any infrastructural development a country cannot possibly attain economic development. Private foreign investors in developing countries have hardly been engaged in infrastructural development as investments in infrastructural sectors / industries do not generate much profit for them. Thus, it falls on developing countries themselves to develop their infrastructure. It is also worth considering whether a developing country should invite private foreign investors to introduce higher technology to them. Any high burdencreating assistance should be avoided.
In order to attract assistance, on the other hand, developing countries should also provide confidence in the minds of private foreign investors by guaranteeing that their investments will not be expropriated, and, amongst other issues, provide protection in the form of effective legislation and reliable judicial systems, and judiciaries. Private foreign investors should not be subject to any discriminatory treatment either. Secure investments also contribute to forming lasting friendships and mutual cooperation between countries. Bilateral investments and trade matters bring the contracting parties closer to each other and form the platform for co-operation.

\section{CONCLUSIONS}

The Tsunami earthquake should be regarded as a wake up alarm for both North and South. The gap between North and South is too wide. The lack of any industrial might in the South means that in general most economies in that part of the world must cling to the agricultural sector, including fisheries and low-tech industries such as textiles, shoe-making etc. Tourism in developing countries is not in general a sophisticated service industry, particularly in the suburban areas where areas of natural beauty abound. This industry is risk-prone in the South.

The Brandt Commission's recommendation on NorthSouth dialogue not only identified the areas in which cooperation between the North and South would be needed but also how the platform for co-operation would be built. "Co-operation" means working together to same end. Thus, if any two parties do not work together the end may not be achieved. In 1983, the Brandt Commission reflected on the progress, on the North-South initiatives of the 1970's but was in general, disappointed.

In this process, both parties must understand each other's needs. Irrespective of whether the Tsunami took place or not, developing countries should have sought help in securing their resorts for foreign visitors, as private foreign investors could have developed a dialogue as to how their sources of income from tourism could have been made more secure. It is re-iterated that Tsunami primarily destroyed the structurally weak resorts and areas of natural beauty.

There is another dimension to this problem. The initiative to improve their economies and industries should be taken by developing countries themselves, otherwise private foreign investors may be accused of encroaching upon the sovereignty of these states. Alternatively, assistance from the relevant international organisations should be sought; countries should not rest on their laurels by claiming that current conditions are "loved" by foreign tourists. The issue of a secure business policy should have been considered.

What is really needed is an understanding between North and South. The ODI (Overseas Development Institute) Report of April 2004 entitled "European 
Development Co-operation to 2010" stated inter alia (at p 2) that:

"In 2001, developing countries supplied 10\% of total EU25 imports and took 9\% of total exports. By contrast, developing countries relied more heavily on the EU as both a consumer and supplier.

ACP exports to the EU-25 have stagnated at around \$27 billion (about 40\% of their total exports) for almost thirty years, so their share in total EU-25 imports has been declining."

In its press release of 15 August 2003, the World Development Movement (WDM) quoted part of the statement made by its Head of Policy:

"The EU claims to be pursuing a development agenda while ignoring the wishes of the majority of developing countries.
Many of these countries have very limited negotiating resources."

In the context of this article it would be inappropriate to go into the issue of "institutional inaction" or the WTO as a policy-making forum for international trade. One may only refer to the Cancún episode, and the subsidy sagas, amongst others, of GSP, MFN etc. The 1970's NorthSouth dialogue initiative has failed, but everybody should carry out soul-searching to identify the causes of its failure. (c)

\section{Dr C Chatterjee}

LL M (Cambridge), LL M, PhD (London); Barrister, Law Department, London Metropolitan University 